\title{
Climatic factors influencing triatomine occurrence in Central-West Brazil
}

\author{
Joyce Mendes Pereira ${ }^{1,2}$, Paulo Silva de Almeida ${ }^{3}$, Adair Vieira de Sousa ${ }^{4}$, \\ Aécio Moraes de Paula ${ }^{5}$, Ricardo Bomfim Machado ${ }^{6}$, Rodrigo Gurgel-Gonçalves ${ }^{7 /+}$
}

\begin{abstract}
${ }^{1}$ Núcleo de Medicina Tropical 'Laboratório de Parasitologia Médica e Biologia de Vetores, Área de Patologia, Faculdade de Medicina ${ }^{6}$ Departamento de Zoologia, Instituto de Biologia, Universidade de Brasília, Brasília, DF, Brasil ${ }^{2}$ Coordenação Geral de Laboratórios de Saúde Pública, Secretaria de Vigilância em Saúde, Ministério da Saúde, Brasília, DF, Brasil ${ }^{3}$ Núcleo Regional de Saúde,

Laboratório Regional de Entomologia, Secretaria de Estado de Saúde, Dourados, MS, Brasil ${ }^{4}$ Núcleo de Apoio ao Controle de Endemias, Secretaria de Saúde, Goiânia, GO, Brasil ${ }^{5}$ Laboratório de Entomologia, Secretaria de Saúde, Cuiabá, MT, Brasil
\end{abstract}

We estimated the geographic distributions of triatomine species in Central-West Region of Brazil (CW) and analysed the climatic factors influencing their occurrence. A total of 3,396 records of 27 triatomine species were analysed. Using the maximum entropy method, ecological niche models were produced for eight species occurring in at least 20 municipalities based on 13 climatic variables and elevation. Triatoma sordida and Rhodnius neglectus were the species with the broadest geographic distributions in CW Brazil. The Cerrado areas in the state of Goiás were found to be more suitable for the occurrence of synanthropic triatomines than the Amazon forest areas in the northern part of the state of Mato Grosso. The variable that best explains the evaluated models is temperature seasonality. The results indicate that almost the entire region presents climatic conditions that are appropriate for at least one triatomine species. Therefore, it is recommended that entomological surveillance be reinforced in CW Brazil.

Key words: Triatominae - ecological niches - Central-West Brazil - entomological surveillance - Chagas disease

Chagas disease (CD) is a chronic and potentially fatal infection caused by the protozoan Trypanosoma cruzi (Chagas 1909). The principal mode of transmission for this parasite is via haematophagous insects of the subfamily Triatominae (Lent \& Wygodzinsky 1979) and control of synanthropic triatomines is the main strategy for preventing human infection (Coura \& Dias 2009, Coura \& Viñas 2010).

At present, there are 143 known species of triatomines and one fossil specimen has been described (Galvão et al. 2003, Costa et al. 2006, Costa \& Felix 2007, Schofield \& Galvão 2009, Frías-Lasserre 2010, Rosa et al. 2012). In Brazil, 63 species have been documented, but only a few of these are relevant in terms of their synanthropic potential (Silveira et al. 1984, Costa et al. 2003, Gurgel-Gonçalves et al. 2012b, Rosa et al. 2012). In 2006, Brazil was declared free of CD transmission by the domestic vector Triatoma infestans (Schofield et al. 2006, Silveira \& Dias 2011). Nevertheless, acute cases of human disease caused by transmission via native triatomine species are still being registered (MS/SVS 2012). Triatomines continue to infest homes in a number of states in Brazil (Oliveira \& Silva 2007, Almeida et al. 2008, Villela et al. 2009, Gurgel-Gonçalves et al. 2010, Silva et al. 2011, 2012, Maeda et al. 2012).

Financial support: CAPES, CNPq

RBM was supported by a fellowship from CNPq.

+Corresponding author: rgurgel@unb.br

Received 9 April 2012

Accepted 18 September 2012
Studies addressing the geographic distributions of triatomines and underlying factors are of fundamental importance for understanding the risk of $\mathrm{CD}$ transmission. Specific climatic conditions can influence the occurrence of triatomines (Bustamante et al. 2007). Ecological niche modelling (ENM) is an approach that permits the exploration of geographic and ecologic phenomena based on known occurrences of species (Peterson 2011). In recent years, ENM has been widely applied in research addressing the geographic distribution of triatomines (Costa \& Peterson 2012, Gurgel-Gonçalves et al. 2012b).

Acute CD cases have been observed less frequently in the Central-West Region of Brazil (CW) than in other parts of the country: a total of 32 cases were registered in this region from 2007-2011, mainly in the state of Goiás (GO) (MS/SVS 2012). However, the risk of vectorial transmission of $T$. cruzi to humans persists, given the continuing presence of triatomines in domiciliary and peridomiciliary environments. Up-to-date knowledge of the geographic distributions of triatomines and the factors influencing their occurrence can aid in planning vectorial surveillance and control measures to be undertaken in the region. The objective of the present study was to estimate the geographic distributions of triatomine species in $\mathrm{CW}$ and analyse the climatic factors influencing their occurrence.

\section{MATERIALS AND METHODS}

Study area - CW comprises the states of Mato Grosso (MT), Mato Grosso do Sul (MS) and GO, as well as the Federal District (DF) of Brazil, Brasília. According to the 2010 census conducted by the Brazilian Institute of Geography and Statistics, the region occupies an area of $1,606,372 \mathrm{~km}^{2}$ distributed among 466 municipalities, the 
majority of which are located in GO. The total population of CW is $14,050,340$ people, most of whom (89\%) reside in urban areas. Geographically, CW is formed by the central and meridional plateaus and the Pantanal plains. Cerrado is the prevailing biome in terms of its areal extent, but the region also includes areas of Pantanal, remnants of Atlantic forest, Amazon rain forest and enclaves of dry forests (WWF 2012). Its tropical climate is characterised by two well-defined periods: a rainy summer, between October-March and a dry winter, from April-September.

Distributional data - Information regarding the occurrence of triatomine species was provided by the Program for Chagas Disease Control (PCDCh) based on captures in domiciliary environments between 20002010. PCDCh conducts both active research (a household survey conducted by community health workers at least once per year) and entomological surveillance with community participation (reports by residents of triatomine occurrence to health workers), in accordance with the classification of risk among municipalities (Silveira 2004). At present, most municipalities in CW give priority to surveillance with community participation.

Data on the occurrence of triatomine species in domiciliary environments between 1975-1983 were also taken into account (Silveira et al. 1984), as were data from other studies (Silva \& Lustosa 1993, Carcavallo et al. 1999, 2002, Carcavallo \& Jurberg 2000, Oliveira \& Silva 2007, Almeida et al. 2008, Gurgel-Gonçalves \& Silva 2009, Gurgel-Gonçalves et al. 2012b, Maeda et al. 2012, Obara et al. 2012). In addition, records of triatomines in the collections of Rodolfo Carcavallo and Herman Lent at the National and International Reference Laboratory on Triatomine Taxonomy at the Oswaldo Cruz Institute, Oswaldo Cruz Foundation, were analysed.

Predictor variables - To build ecological niche models for triatomine species, data on climate and elevation were obtained from the WorldClim project (worldclim. org). These variables are obtained through the interpolation of mean monthly climatic data obtained from meteorological stations over a period of $30(1960-1990)$ to 50 (1950-2000) years, depending on their availability at the stations (Hijmans et al. 2005). The environmental data used in the analyses cover Central and South America at a spatial resolution of $2.5^{\prime}$ ( 5 x $5 \mathrm{~km}$ per pixel). Only variables that were not strongly correlated $(\mathrm{r}<0.8)$ were used in building the models (Table).

$E N M$ - Data on a total of 3,396 occurrences of 27 triatomine species were assembled. These occurrences were referenced to geographic coordinates with an uncertainty of $\leq 5 \mathrm{~km}$ and precision of $0.01^{\circ}$, which is a degree of error that should not dramatically influence the results. Records of triatomine species presenting georeferencing or identification errors were eliminated. The records were georeferenced based on data available from fallingrain.com/ world and ibge.gov.br. We only analysed species for which 20 unique occurrence points were available (Stockwell \& Peterson 2002, Wisz et al. 2008), resulting in eight total species: Triatoma pseudomaculata, Triatoma sordida, Triatoma williami, Triatoma costalimai, Panstrongylus megistus, Panstrongylus diasi, Panstrongylus geniculatus and Rhodnius neglectus.

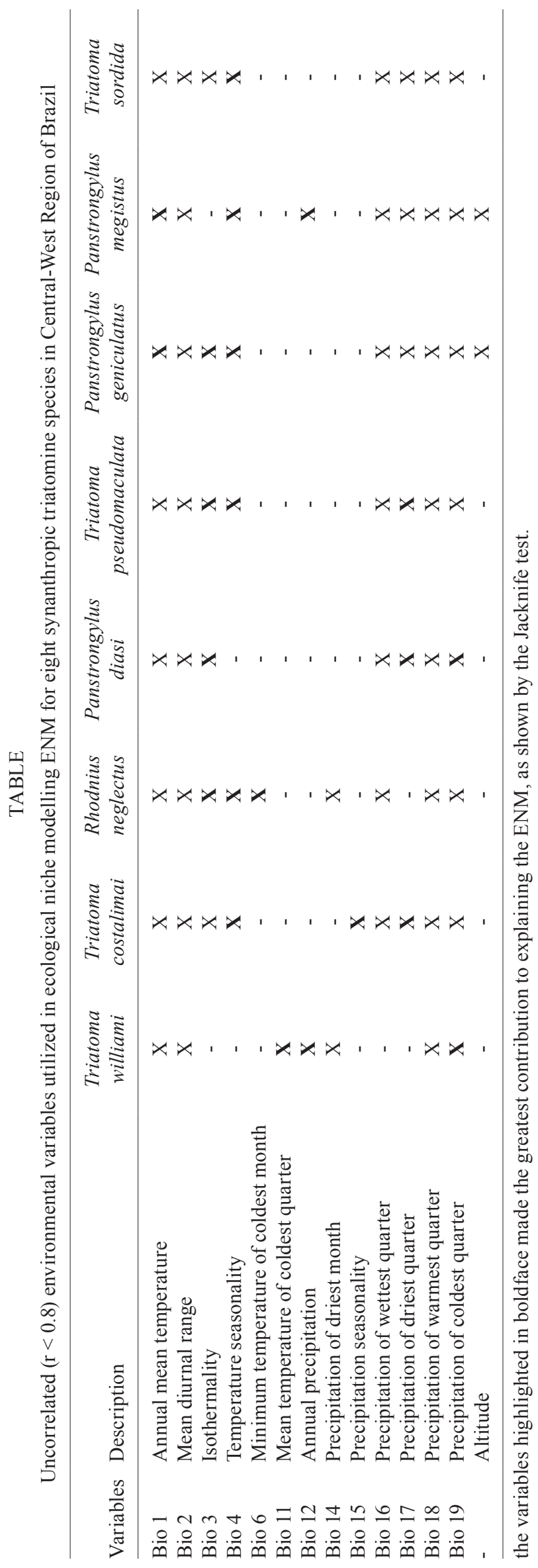


Maps of potential species distributions were produced using Maxent version 3.2.1 (Phillips et al. 2006) applying the default parameters, which are considered appropriate for most situations. The choice of methodology took into consideration the particular characteristics of the study area, i.e., the area of interest is the area sampled, with no need for transferring models over broader or other landscapes (Elith et al. 2006, Peterson et al. 2007).

Occurrence data were separated into two sets: one for model calibration ( $80 \%$ of points) and the other for model evaluation (20\% of points). Subsequently, raw maxent outputs were converted into binary maps showing the presence or absence of each species based on a threshold that includes $90 \%$ of the records of each species used in model calibration (Pearson et al. 2007, Peterson et al. 2008). The analyses were focused on the species diversity of broadly distributed triatomines. Thus, we summed the final, thresholded map for each of the eight species using the Spatial Analyst extension of ArcView 3.3 (Environment System Research Institute Inc - Geographical Information System, Redlands, CA). Given the binary nature of each map, the sums yield a hypothesis regarding the numbers of species (triatomine species richness) present across the study region.

With respect to the occurrence maps for the remaining triatomine species, only point maps were generated, using TerraView version 4.0.0. The digital mesh network (in shape file format) for Brazil was obtained from siscom.ibama.gov.br/ and subsequently edited for CW.

Model validation - The quality of the models generated was evaluated using the receiver operating characteristic (ROC) curve, which correlates the sensitivity and specificity of model predictions across multiple thresholds (Phillips et al. 2006). The area under the ROC curve (AUC) provides a measure of model performance across many thresholds. AUC values close to one indicate high performance, while readings below 0.5 indicate poor performance of the model (Elith et al. 2006).

To test the models' significance, we compared the predictive power of the models against a random null hypothesis. After developing a model, we checked whether test points fell into areas predicted to be present more often than expected at random, given the overall proportion of pixels showing predicted presence vs. predicted absence for that species. In addition to the model significance (departure from random predictions), we assessed model accuracy by examining the proportion of test points falling into regions of predicted presence (Anderson et al. 2002). Using Maxent's internal Jackknife test, the variables that most influence the distribution of triatomine species were identified.

\section{RESULTS}

A total of 27 triatomine species were recorded in the CW region: T. sordida, T. pseudomaculata, T. williami, T. infestans, T. costalimai, Triatoma baratai, Triatoma matogrossensis, Triatoma lenti, Triatoma jurbergi, Triatoma guazu, Triatoma deaneorum, Triatoma vandae, $P$. megistus, $P$. diasi, $P$. geniculatus, Panstrongylus guentheri, Panstrongylus lenti, $R$. neglectus, Rhodnius picti- pes, Rhodnius robustus, Rhodnius stali, Psammolestes tertius, Psammolestes coreodes, Microtriatoma trinidadensis, Microtriatoma borbai, Eratyrus mucronatus and Cavernicola pilosa. This set of species accounts for $42.8 \%$ of the 63 known species in Brazil. MT was the state with the greatest number of triatomine species (n $=17,63 \%)$, followed by MS ( $\mathrm{n}=15,55.5 \%), \mathrm{GO}(\mathrm{n}=14$, $52 \%)$ and the DF ( $\mathrm{n}=7,26 \%)$.

The genus Triatoma presented the greatest species richness ( $\mathrm{n}=12$ species). $T$. sordida was the most widely distributed species (Figs. 1, 2). The genus Panstrongylus was represented by five species, among which $P$. geniculatus was the most widespread (Fig. 2). Four species of the genus Rhodnius were registered, of which $R$. neglectus was the most widespread (Fig. 2). Other genera, such as Psammolestes, Microtriatoma, Eratyrus and Cavernicola, exhibited few species and very limited distributions (Fig. 1). Only one occurrence of $T$. infestans was recorded in the year 2000 (in GO). The species T. jurbergi, T. guazu, R. robustus, M. trinidadensis, $M$. borbai, E. mucronatus and C. pilosa (Fig. 1) presented very restricted geographical distributions, with occurrences registered in just one municipality.

All of the models derived from the analysis performed well (AUC > 0.90), summarising the necessary ecological conditions for the occurrence of the species. All models showed sensitivities greater than $98 \%$. The binomial probabilities were statistically significant for the species $(\mathrm{p}<0.01)$. The map aggregating the ecological niche models for eight species (Fig. 3) indicated greater climatic suitability for the occurrence of triatomines in Cerrado areas in GO in comparison to Amazon forest areas in northern MT. The Jackknife tests showed that temperature seasonality was the variable that best explained the models (Table).
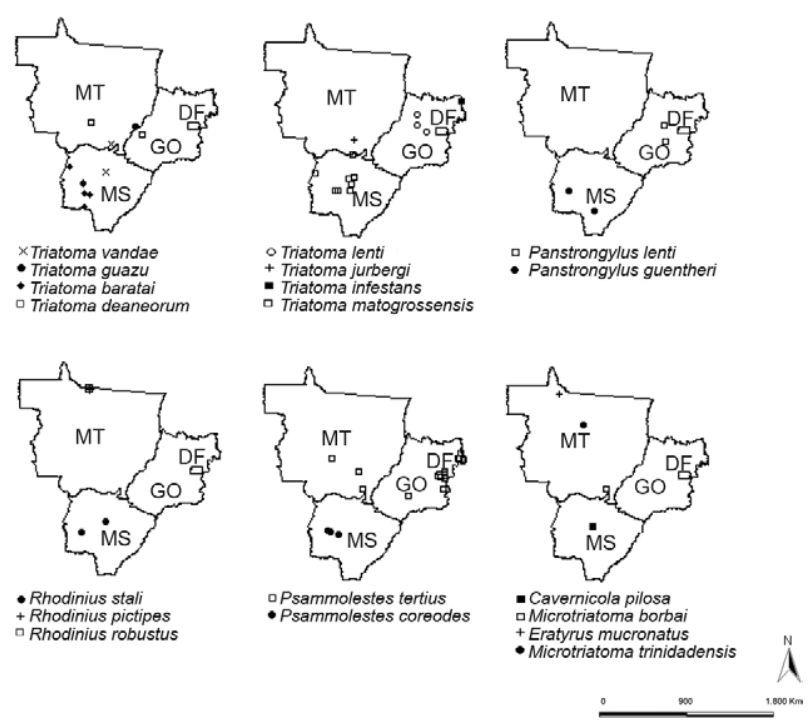

Fig 1: geographic distribution of triatomine species with $<20$ known occurrences in Central-West Region of Brazil. DF: Federal District; GO: state of Goiás; MS: state of Mato Grosso do Sul; MT: state of Mato Grosso. 


\section{DISCUSSION}

This study indicates that there is a rich triatomine fauna in CW. Almost half of all known species in Brazil are represented in the region. Indeed, nearly the entire region offers favourable conditions for the occurrence of at least one triatomine species. Furthermore, our results show that the triatomine occurrence is greater in the Cerrado biome, where there are major seasonal temperature variations. The results of this study serve to update the list of triatomine species in CW. Oliveira \& Silva (2007) registered nine species in $\mathrm{GO}$, which is fewer than the 14 species registered in the present study. Almeida et al. (2008) reported 12 species in MS, also fewer than the 15 recorded in our list. Finally, Figueiredo et al. (2007) reported five species from MT, while we registered 17 species. The greater triatomine diversity observed in MT is most likely a function of the size of this state and of the diversity of its biomes (Cerrado, Amazon rainforest and Pantanal). Analysis of the ENM maps showed less climatic suitability for the occurrence of synanthropic triatomines in northern MT, where Amazon rainforest predominates. The lower diversity of synanthropic triatomines in rainforest areas reinforces the hypothesis that the chances of domiciliary infestation by triatomines are greater in drier regions (Abad-Franch \& Monteiro 2007).
T. sordida and $R$. neglectus were the species showing the broadest geographic distributions in CW. Both species are capable of adapting to different ecosystems, as has been noted by other authors (Lent \& Wygodzinsky 1979, Forattini 1980, Gurgel-Gonçalves \& Cuba 2009, Gurgel-Gonçalves et al. 2011, 2012b). Although it is the most frequently encountered species in Brazil, T. sordida occurs mainly in peridomicile areas and generally feeds on birds, which reduces the probability of vectorial transmission of T. cruzi to humans (Diotaiuti et al. 1993). $R$. neglectus frequently inhabits palm trees in CW (Barretto et al. 1969, Gurgel-Gonçalves et al. 2004, AbadFranch et al. 2009, Gurgel-Gonçalves \& Cuba 2009), where it participates actively in the enzootic transmission of T. cruzi and Trypanosoma rangeli (Gurgel-Gonçalves et al. 2012a); this species has been documented in domiciliary environments in recent years (Oliveira \& Silva 2007, Almeida et al. 2008, Gurgel-Gonçalves et al. 2008), which may be related to ecological processes that stimulate the invasion of artificial ecotopes by potentially infected individuals (Abad-Franch et al. 2009).

T. costalimai appears to be endemic to the Cerrado. This species has been frequently collected on limestone outcrops in peridomiciliary environments in northeastern GO (Mello 1982, Lorosa et al. 1999, Machiner et al.
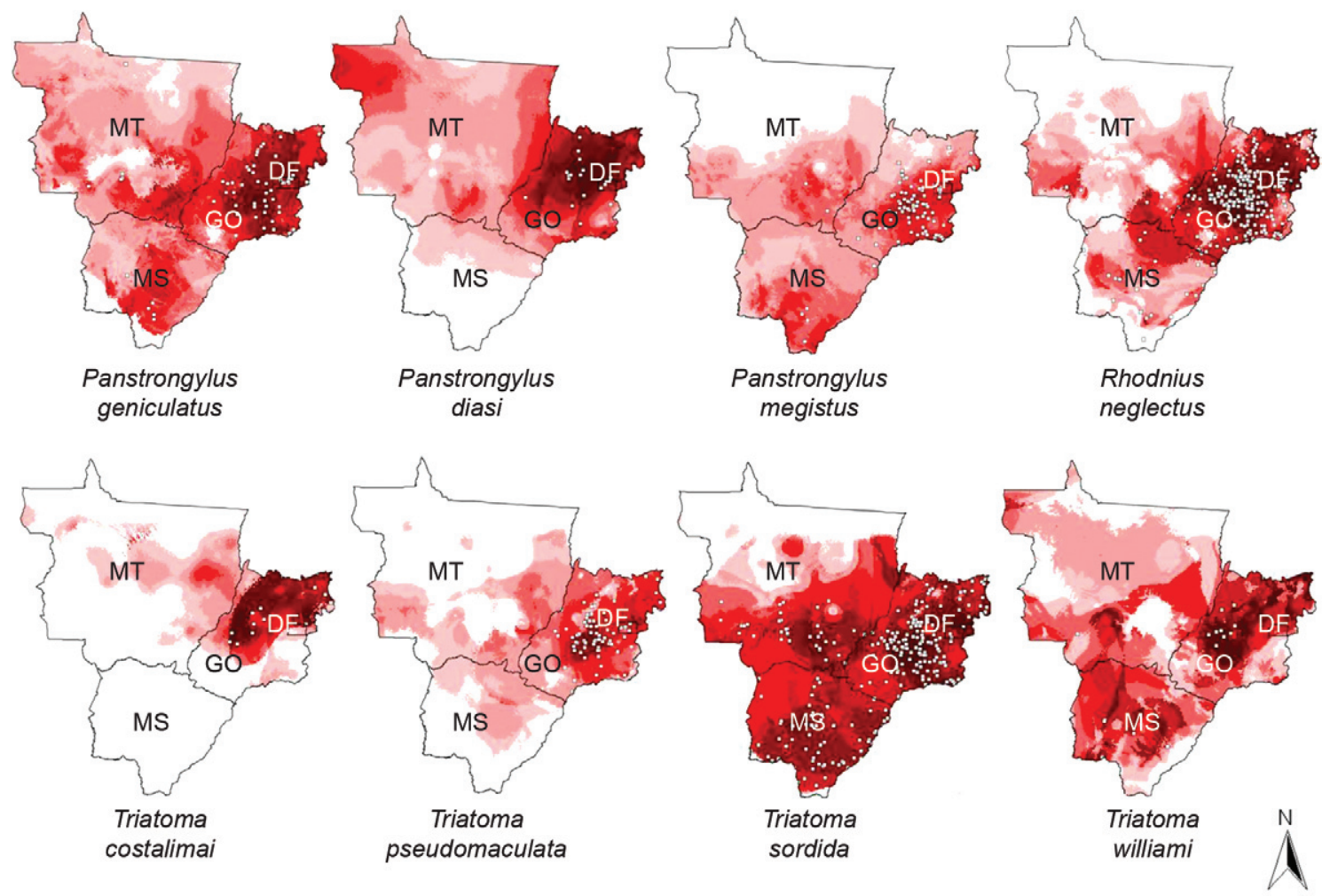

0

900

$1.800 \mathrm{Km}$

Fig 2: maps of potential distribution derived from ecological niche models for triatomine species with $>20$ occurrences in Central-West Region of Brazil. Blank areas represent triatomine absence predicted by the model. Areas identified as suitable based on climatic variables are shown in red scale: light red (low suitability) to dark red (high suitability). Dots represent known occurrences of the triatomine species. DF: Federal District; GO: state of Goiás; MS: state of Mato Grosso do Sul; MT: state of Mato Grosso. 
2012). However, our findings point to areas that are propitious for this species in eastern GO and even in MT, where T. williami, a similar species (Obara et al. 2012), has been reported. Thus, the co-occurrence of these species in GO may be likely. More detailed studies of the ecological niches of these species are needed to understand their distributional limits. Our results indicate that T. williami also occurs in areas of the Pantanal in the northwest of MS. Although individuals of this species have been found to be infected in domiciliary environments (Arrais-Silva et al. 2011), little is known about their biology and their natural habitat is still unknown.

T. pseudomaculata, a species that is widespread in northeastern Brazil with a known ability to infest artificial ecotopes (Carcavallo et al. 1999, Assis et al. 2007), occurs only in GO and the DF. Our results show lower climatic suitability for T. pseudomaculata in MT and $\mathrm{MS}$, in agreement with the findings of Carbajal de la Fuente et al. (2009), who used different environmental variables to produce potential distribution maps. The historical occurrence of $T$. infestans in the municipality of Posse in GO was recorded in 2000; this population was also observed by Oliveira and Silva (2007). Additionally, Gurgel-Gonçalves et al. (2012c) reported residual foci of T. infestans in Bahia (BA). Thus, the areas along the border line between $\mathrm{GO}$ and $\mathrm{BA}$ should be monitored to prevent re-infestations by T. infestans in GO.

Among the Panstrongylus, P. geniculatus showed the greatest potential for occurrence in $\mathrm{CW}$. In contrast, $P$. megistus was indicated as absent from northern MT and $P$. diasi was predicted to be absent in southern MS. P. geniculatus occurs in at least 16 countries in the Americas. In contrast, $P$. diasi appears to be endemic to the Brazilian Cerrado (Carcavallo et al. 1999), while

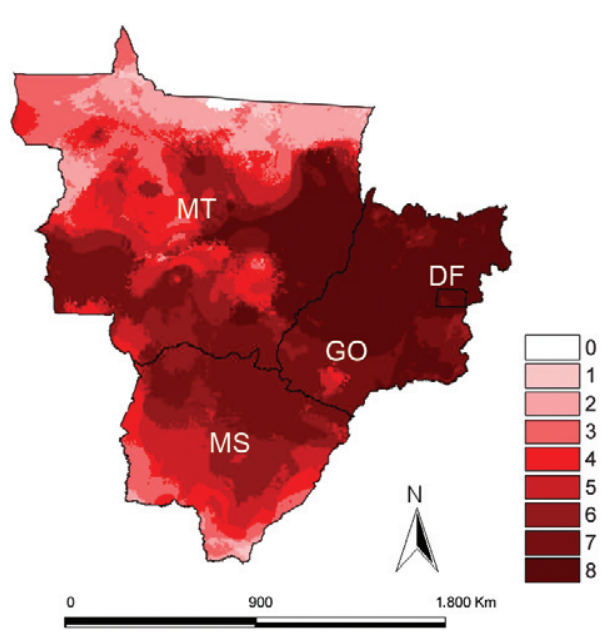

Fig 3: final model of climatic suitability for eight triatomine species in Central-West Region of Brazil, summing binary models versions of potential distributions derived from ecological niche. Blank areas represent zero species diversity predicted; the red scale indicates numbers of species expected, with light red indicating few species and dark red indicating many. DF: Federal District; GO: state of Goiás; MS: state of Mato Grosso do Sul; MT: state of Mato Grosso. the distribution of P. megistus is centred in the Atlantic forest (Forattini 1980) and its occurrence in the Cerrado seems to be greater in humid areas (gallery forests).

Among the analysed climatic variables, temperature seasonality was found to best explain the models of triatomine occurrence in CW. A greater number of synanthropic triatomine species was observed in areas with greater seasonal temperature variation. Other studies have shown temperature to be an important determinant of the distribution of triatomines on a regional or continental scale (Gorla 2002, Rodriguero \& Gorla 2004, Batista \& Gurgel-Gonçalves 2009, Gurgel-Gonçalves \& Silva 2009, Gurgel-Gonçalves et al. 2011). However, other environmental variables, such as the slope of the terrain (Leite et al. 2011) and humidity (Arboleda et al. 2009), have also been identified as principal determinants of the occurrence of certain species.

The basic strategies for CD vector surveillance in $\mathrm{CW}$ are as follows: monitoring the possible re-infestation of $T$. infestans and reducing the domiciliary infestation of native triatomines with widespread geographic distributions, as described in this paper. Therefore, it is recommended that entomological surveillance be reinforced in CW.

\section{ACKNOWLEDGEMENTS}

To all the health agents of the Central-West Region of Brazil, for providing information on the distribution of triatomines, and to César Augusto Cuba Cuba, Jane Costa, Pedro Tauil, Marcos T Obara and A Townsend Peterson, for reviewing the paper.

\section{REFERENCES}

Abad-Franch F, Monteiro FA 2007. Biogeography and evolution of Amazonian triatomines (Heteroptera: Reduviidae): implications for Chagas disease surveillance in humid forest ecoregions. Mem Inst Oswaldo Cruz 102 (Suppl. I): 57-69.

Abad-Franch F, Monteiro FA, Jaramillo NO, Gurgel-Gonçalves R, Dias FBS, Diotaiuti L 2009. Ecology, evolution and the long-term surveillance of vector-borne Chagas disease: a multi-scale appraisal of the tribe Rhodniini (Triatominae). Acta Trop 112: 159-177.

Almeida PS, Ceretti Júnior W, Obara MT, Santos HR, Barata JM, Faccenda O 2008. Levantamento da fauna de Triatominae (Hemiptera: Reduviidae) em ambiente domiciliar e infecção natural por Trypanosomatidae no estado de Mato Grosso do Sul. Rev Soc Bras Med Trop 41: 374-380.

Anderson RP, Gómez-Laverde M, Peterson AT 2002. Geographical distributions of spiny pocket mice in South America: insights from predictive models. Global Ecol Biogeogr 11: 131-141.

Arboleda S, Gorla DE, Porcasi X, Saldaña A, Calzada J, Jaramillo N 2009. Development of a geographical distribution model of Rhodnius pallescens Barber, 1932 using environmental data recorded by remote sensing. Infect Genet Evol 9: 441-448.

Arrais-Silva WW, Rodrigues RSV, Moraes LN, Venere PC, Lunardi RR, Souza IL, Souto PCS 2011. First report of occurrence of Triatoma williami Galvão, Souza e Lima, 1965 naturally infected with Trypanosoma cruzi Chagas, 1909 in the state of Mato Grosso, Brazil. Asian Pac J Trop Dis 2011: 245-246.

Assis GFM, Azeredo BVM, Carbajal de la Fuente AL, Diotaiuti L, Lana M 2007. Domiciliation of Triatoma pseudomaculata (Corrêa and Espínola 1964) in the Jequitinhonha Valley, state of Minas Gerais. Rev Soc Bras Med Trop 40: 391-396.

Barretto MP, Albuquerque DRR, Funayama GK 1969. Estudos sobre reservatórios e vectores silvestres do Trypanosoma cruzi. XXX- 
VI. Investigação sobre triatomíneos de palmeiras no município de Uberaba, MG, Brasil. Rev Bras Biol 29: 577-588.

Batista TA, Gurgel-Gonçalves R 2009. Ecological niche modelling and differentiation between Rhodnius neglectus Lent, 1954 and Rhodnius nasutus Stål, 1859 (Hemiptera: Reduviidae: Triatominae) in Brazil. Mem Inst Oswaldo Cruz 104: 1165-1170.

Bustamante DM, Monroy MC, Rodas AG, Juarez JA, Malone JB 2007. Environmental determinants of the distribution of Chagas disease vectors in south-eastern Guatemala. Geospat Health 1: 199-211.

Carbajal de la Fuente AL, Porcasi X, Noireau F, Diotaiuti L, Gorla DE 2009. The association between the geographic distribution of Triatoma pseudomaculata and Triatoma wygodzinskyi (Hemiptera: Reduviidae) with environmental variables recorded by remote sensors. Infect Genet Evol 9: 54-61.

Carcavallo RU, Curto de Casas SI, Sherlock I, Galíndez Girón I, Jurberg J, Galvão C, Mena Segura CA, Noireau F 1999. Geographical distribution and alti-latitudinal dispersion. In Atlas of Chagas disease vectors in Americas, Vol. III, Fiocruz, Rio de Janeiro, p. 747-792.

Carcavallo RU, Jurberg J 2000. Triatoma baratai sp. n. do estado do Mato Grosso do Sul (Hemiptera, Reduviidae, Triatominae). Entomol Vect 7: 373-387.

Carcavallo RU, Jurberg J, Rocha DS, Galvão C, Noireau F, Lent H 2002. Triatoma vandae $\mathrm{sp}$. $\mathrm{n}$. do complexo oliveirai encontrada no estado de Mato Grosso, Brasil (Hemiptera: Reduviidae: Triatominae). Mem Inst Oswaldo Cruz 97: 649-654.

Chagas C 1909. Nova tripanozomiaze humana. Estudos sobre a morfolojia e o ciclo evolutivo de Schizotrypanum cruzi n. gen., n. sp., ajente etiolojico de nova entidade morbida do homem. Mem Inst Oswaldo Cruz 1: 159-218.

Costa J, Almeida CE, Dotson EM, Lins A, Vinhaes M, Silveira AC, Beard CB 2003. The epidemiologic importance of Triatoma brasiliensis as a Chagas disease vector in Brazil: a revision of domiciliary captures during 1993-1999. Mem Inst Oswaldo Cruz 98: 443-449.

Costa J, Argolo AM, Felix M 2006. Redescription of Triatoma melanica Neiva \& Lent, 1941, new status (Hemiptera: Reduviidae: Triatominae). Zootaxa 1385: 47-52.

Costa J, Felix M 2007. Triatoma juazeirensis sp. nov. from the state of Bahia, northeastern Brazil (Hemiptera: Reduviidae: Triatominae). Mem Inst Oswaldo Cruz 102: 87-90.

Costa J, Peterson AT 2012. Ecological niche modeling as a tool for understanding distributions and interactions of vectors, hosts and etiologic agents of Chagas disease. In AT Peterson (ed.)., Recent advances on model hosts, Vol. I, Springer, Kansas, p. 59-70.

Coura JR, Dias JCP 2009. Epidemiology, control and surveillance of Chagas disease - 100 years after its discovery. Mem Inst Oswaldo Cruz 104 (Suppl. I): 31-40.

Coura JR, Viñas PA 2010. Chagas disease: a new worldwide challenge. Nature 465: 56-57.

Diotaiuti L, Loiola CF, Falcão PL, Dias JCP 1993. The ecology of Triatoma sordida in natural environments in two different regions of the state of Minas Gerais, Brazil. Rev Inst Med Trop Sao Paulo 35: 237-245.

Elith JC, Graham C, Anderson R, Dudík M, Ferrier S, Guisan A, Hijmans R, Huettmann F, Leathwick J, Lehmann A, Li J, Lohmann L, Loisell B, Manion G, Moritz C, Nakamura M, Nakazawa Y, Overton J, Peterson AT, Phillips S, Richardson K, ScachettiPereira R, Schapire E, Soberón J, Williams S, Wisz M, Zimmerman N 2006. Novel methods improve prediction of species distributions from occurrence data. Ecography 29: 129-151.

Figueiredo JF, Silva LC, Bolognez CA 2007. Influência das agressões ecológicas na migração de triatomíneos (Hemiptera: Reduviidae) para os ecótopos artificiais criados pelo homem em municípios do estado de Mato Grosso. Biodiversidade 6: 52-61.

Forattini OP 1980. Biogeografia, origem e distribuição da domiciliação de triatomíneos no Brasil. Rev Saude Publica 14: 265-299.

Frías-Lasserre D 2010. A new species and karyotype variation in the bordering distribution of Mepraia spinolai (Porter) and $\mathrm{Me}$ praia gajardoi Frías et al. (Hemiptera: Reduviidae: Triatominae) in Chile and its parapatric model of speciation. Neotrop Entomol 39: 572-583.

Galvão C, Carcavallo RU, Rocha DS, Jurberg J 2003. A checklist of the current valid species of the subfamily Triatominae Jeannel, 1919 (Hemiptera, Reduviidae) and their geographical distribution, with nomenclatural and taxonomic notes. Zootaxa 202: 1-36.

Gorla DE 2002. Variables ambientales registradas por sensores remotos como indicadores de la distribución geográfica de Triatoma infestans (Heteroptera: Reduviidae). Ecol Austral 12: 117-127.

Gurgel-Gonçalves R, Abad-Franch F, Ferreira JBC, Santana DB, Cuba CAC 2008. Is Rhodnius prolixus (Triatominae) invading houses in central Brazil? Acta Trop 107: 90-98.

Gurgel-Gonçalves R, Cuba CAC 2009. Predicting the potential geographical distribution of Rhodnius neglectus (Hemiptera, Reduviidae) based on ecological niche modeling. J Med Entomol 46: 952-960.

Gurgel-Gonçalves R, Cura C, Schijman AG, Cuba CAC 2012a. Infestation of Mauritia flexuosa palms by triatomines (Hemiptera: Reduviidae), vectors of Trypanosoma cruzi and Trypanosoma rangeli in the Brazilian savanna. Acta Trop 121: 105-111.

Gurgel-Gonçalves R, Duarte MA, Ramalho ED, Romaña CA, Cuba CAC 2004. Distribuição espacial de populações de Triatominae (Hemiptera, Reduviidae) em palmeiras da espécie Mauritia flexuosa no Distrito Federal, Brasil. Rev Soc Bras Med Trop 37: 241-247.

Gurgel-Gonçalves R, Ferreira JBC, Rosa AF, Bar ME, Galvão C 2011. Geometric morphometrics and ecological niche modelling for delimitation of near-sibling triatomine species. Med Vet Entomol 25: 84-93.

Gurgel-Gonçalves R, Galvão C, Costa J, Peterson AT 2012b. Geographic distribution of Chagas disease vectors in Brazil based on ecological niche modeling. J Trop Med 2012: 1-15.

Gurgel-Gonçalves R, Galvão C, Mendonça J, Costa-Neto RM 2012c. Guia de triatomíneos da Bahia, Universidade Estadual de Feira de Santana, Feira de Santana, 112 pp.

Gurgel-Gonçalves R, Pereira FCA, Lima IP, Cavalcante RR 2010. Distribuição geográfica, infestação domiciliar e infecção natural de triatomíneos (Hemiptera: Reduviidae) no estado do Piauí, Brasil, 2008. Rev Pan-Amaz Saude 1: 57-64.

Gurgel-Gonçalves R, Silva RB 2009. Analysis of the geographical distribution of Psammolestes Bergroth (Heteroptera: Reduviidae) in South America with new records of Psammolestes tertius Lent \& Jurberg. Zootaxa 2033: 41-48.

Hijmans RJ, Cameron SE, Parra JL, Jones PG, Jarvis A 2005. Very high resolution interpolated climate surfaces for global land areas. Int J Climatol 25: 1965-1978.

Leite GR, Santos CB, Falqueto A 2011. Influence of the landscape on dispersal of sylvatic triatomines to anthropic habitats in the Atlantic Forest. J Biogeogr 38: 651-663.

Lent H, Wygodzinsky P 1979. Revision of the Triatominae (Hemiptera, Reduviidae) and their significance as vectors of Chagas disease. Bull Am Mus Nat Hist 163: 520-529.

Lorosa ES, Andrade RE, Santos SM, Pereira CA, Vinhaes MC, Jurberg J 1999. Estudo da infecção natural e fontes alimentares de Triatoma costalimai Verano \& Galvão, 1959, Rhodnius neglectus 
Lent, 1954 e Psammolestes tertius Lent \& Jurberg, 1965 do estado de Goiás, Brasil, através da técnica de precipitina. Entomol Vect 6: 405-414.

Machiner F, Cardoso RM, Castro CN, Gurgel-Gonçalves R 2012. Occurrence of Triatoma costalimai (Hemiptera: Reduviidae) in different environments and climatic seasons: a field study in the Brazilian savanna. Rev Soc Bras Med Trop 45: 567-571.

Maeda MH, Knox MB, Gurgel-Gonçalves R 2012. Occurrence of synanthropic triatomines (Hemiptera: Reduviidae) in the Federal District of Brazil. Rev Soc Bras Med Trop 45: 71-76.

Mello DA 1982. Roedores, marsupiais e triatomíneos silvestres capturados no município de Mambaí, Goiás. Infecção natural pelo Trypanosoma cruzi. Rev Saude Publica 16: 282-291.

MS/SVS - Ministério da Saúde/Secretaria de Vigilância em Saúde 2012. [homepage on the Internet]. Doença de Chagas. Aspectos epidemiológicos. [updated 2012 Mai 30; cited 2012 Jun 11]. Available from: portal.saude.gov.br/portal/saude/profissional/ visualizar_texto.cfm?idtxt=31454.

Obara MT, Barata JMS, Rosa JA, Ceretti Junior W, Almeida PS, Gonçalves GA, Dale C, Gurgel-Gonçalves R 2012. Description of the female and new records of Triatoma baratai Carcavallo \& Jurberg, 2000 (Hemiptera, Reduviidae) from Mato Grosso do Sul, Brazil, with a key to the species of the Triatoma matogrossensis subcomplex. Zootaxa 3151: 63-68.

Oliveira AWS, Silva IG 2007. Distribuição geográfica e indicadores entomológicos de triatomíneos sinantrópicos capturados no estado de Goiás. Rev Soc Bras Med Trop 40: 204-208.

Pearson RG, Raxworthy CJ, Nakamura M, Peterson AT 2007. Predicting species distributions from small numbers of occurrence records: a test case using cryptic geckos in Madagascar. $J$ Biogeogr 34: 102-117.

Peterson AT 2011. Ecological niche modeling and spatial patterns of disease transmission. Emerg Infect Dis 12: 1822-1826.

Peterson AT, Papes M, Eaton M 2007. Transferability and model evaluation in ecological niche modeling: a comparison of GARP and Maxent. Ecography 30: 550-560.

Peterson AT, Papes M, Soberón J 2008. Rethinking receiver operating characteristic analysis appications in ecological niche modeling. Ecol Model 213: 63-72.

Phillips SJ, Anderson RP, Schapire RE 2006. Maximum entropy modeling of species geographic distributions. Ecol Model 190: 231-259.

Rodriguero MS, Gorla DE 2004. Latitudinal gradient in species richness of the New World Triatominae (Reduviidae). Global Ecol Biogeogr 13: 75-84.
Rosa JA da, Rocha CS, Gardim S, Pinto MC, Mendonça VJ, Filho JCRF, Carvalho EOC, Camargo LMA, Oliveira J, Nascimento JD, Cilense M, Almeida CE 2012. Description of Rhodnius montenegrensis sp. n. (Hemiptera: Reduviidae: Triatominae) from the state of Rondônia, Brazil. Zootaxa 3478: 62-76.

Schofield CJ, Galvão C 2009. Classification, evolution and species groups within the Triatominae. Acta Trop 110: 88-100.

Schofield CJ, Jannin J, Salvatella R 2006. The future of Chagas disease control. Trends Parasitol 22: 583-588.

Silva EOR, Rodrigues VLCC, Silva RA, Wanderley DMV 2011. Control program of Chagas disease in São Paulo, Brazil: the control and surveillance of vector transmission. Rev Soc Bras Med Trop 44 (Suppl. 2): 74-84.

Silva IG, Lustosa ES 1993. Biologia de Psammolestes tertius Lent \& Jurberg, 1965 (Hemiptera, Reduviidae). Rev Patol Trop 22: 29-42.

Silva MBA, Barreto AVMS, Silva HA, Galvão C, Rocha D, Jurberg J, Gurgel-Gonçalves R 2012. Synanthropic triatomines (Hemiptera, Reduviidae) in the state of Pernambuco, Brazil: geographical distribution and natural Trypanosoma infection rates between 2006 and 2007. Rev Soc Bras Med Trop 45: 60-65.

Silveira AC 2004. Enfoque de riesgo em actividades de control de triatominos. Rev Patol Trop 33: 193-206.

Silveira AC, Dias JCP 2011. O controle da transmissão vetorial. Rev Soc Bras Med Trop 44 (Suppl. 2): 52-63.

Silveira AC, Feitosa VR, Borges R 1984. Distribuição de triatomíneos capturados no ambiente domiciliar no período de 1975/83, Brasil. Rev Bras Malariol Doencas Trop 39: 15-312.

Stockwell DRB, Peterson AT 2002. Effects of sample size on accuracy of species distribution models. Ecol Model 148: 1-13.

Villela MM, Souza JMB, Melo VP, Dias JCP 2009. Avaliação do Programa de Controle da Doença de Chagas em relação à presença de Panstrongylus megistus na região centro-oeste do estado de Minas Gerais, Brasil. Cad Saude Publica 25: 907-917.

Wisz MS, Hijmans RJ, Li J, Peterson AT, Graham CH, Guisan A, Elith J, Dudik M, Ferrier S, Huettman F, Leathwick JR, Lehmann A, Lohamnn L, Loiselle BA, Manion G, Moritz C, Nakamura M, Nakazawa Y, McC Overton J, Phillips SJ, Richardson KS, Scachetti-Pereira R, Schapire RE, Soberón J, Williams SE, Zimmermann NE 2008. Effects of sample size on the performance of species distribution models. Divers Distrib 14: 763-773.

WWF - World Wildlife Fund 2012. [homepage on the Internet]. List of ecoregions [updated 2012 Apr 9; cited 2012 Mar 9]. Available from: wwf.panda.org/ about_our_earth/ecoregions/ ecoregion list/. 